\title{
The Shukūk: Aporetic Commentary
}

In the following chapters, we conduct four case studies in which the contents of five sections of the Shukūk are closely examined. Here in the present chapter, we offer an overview of the organisation and contents of al-Mas'üdì's work, and a reading of the broader motives and method that underlie the book, partly by drawing on some of the findings of the ensuing chapters.

\subsection{Two Genres: Aporetic Commentary (Shukūk), Exegetical Commentary (Sharh)}

The broader intellectual context within which al-Mas'ūdī operated, comprising exponents and critics of Avicennan philosophy, has already been explored at the outset of our previous chapter; and that is certainly the most important background against which the Shukūk must be interpreted. As we shall see in detail in what follows, al-Ghazālī's Tahâfut and Abū l-Barakāt's Mu'tabar are the only sources explicitly referenced in the book, alongside the Ishārāt (and in one place Euclid). Besides these intellectual trends and sources, we must also consider the textual genealogy of al-Mas'ūdī's work, in particular where it is positioned in relation to two distinct commentarial traditions, namely the genre of philosophical and scientific aporetic commentaries and the tradition of exegetical commentaries dedicated to individual Avicennan philosophical texts. $^{1}$

1 My proposed distinction between aporetic and exegetical commentaries differs from Robert Wisnovsky's distinction between 'problem commentaries' and 'system commentaries' ('Avicennism and Exegetical Practice'; 'Avicenna's Islamic Reception', 198-199); the former distinction focuses on the function of a commentary, whereas the latter focuses primarily on scope. Wisnovsky classes al-Rāzī's response to the Shukūk, the Jawābāt, and Sayf al-Dīn alĀmidī's response to al-Rāzī's comprehensive commentary on the Ishārāt, Kashfal-tamwīhāt, as problem commentaries, whereas I class them as exegetical commentaries, as I shall explain shortly. It should be noted here that the distinction between aporetic and exegetical commentaries is meant not as an exhaustive taxonomy, but first and foremost to delineate aporetic texts as a discrete genre. The distinction seems to become less applicable in post-thirteenthcentury Arabic philosophy.

(C) KONINKLIJKE BRILL NV, LEIDEN, 2016 | DOI:10.1163/9789004302532_004

This is an open access chapter distributed under the terms of the CC-BY-NC 4.o License. 
1. The tradition of aporetic commentaries (shukūk). Al-Mas'ūdī originally conceived his book within the genre of aporias, which had already become a small, but well-established specialist genre in Arabic science and philosophy. ${ }^{2}$ The two most important earlier representative texts, originating respectively from the early fourth/tenth and early fifth/eleventh centuries, are Abū Bakr al-Rāzì's al-Shukūk 'alā kalām fā dil al-ațibbā' Jālìnūs fì l-kutub allatī nusibat ilayhi (Problems Raised Concerning Views of Galen, the Most Eminent of Physicians, in the Books Attributed to Him) and Ibn al-Haytham's aporias on Ptolemy, alShukūk 'alā Bațlamyūs. ${ }^{3}$ Al-Mas'ūdī is very likely to have been familiar with the latter book, in view of his interest in the mathematical sciences, especially astronomy. In the preface to his astronomical work the Kifäya, he names Ibn al-Haytham's highly influential book Hay'at al-älam as one of his principal sources, and later on in the same work cites his treatise on 'winding motion' (harakat al-iltifäf). ${ }^{4}$

So how do aporetic texts differ from refutations, which may be marked by a variety of labels, such as $i b t a \bar{l}$, radd and naqd, depending on discipline and context? To answer this question, I propose that the expression shakk (pl. shukük) denotes a problem, or objection, that tends to be relatively narrow in scope and limited in its implications. The import of the expression, accordingly, depends on whether an author employs it with reference to objections that he himself raises, or to objections raised against views which he supports.

The former sense gives us dedicated aporetic works, which typically consist of collections of problems, or puzzles, that the author raises concerning views, mostly of a theoretical nature, propounded by an eminent individual in one or more of his works. The target individual and his works will always be responsible for laying the foundations of a major system within a certain field of scholarship, and will therefore have an authoritative status in that field. The author of the aporetic text is normally an insider to the field, but one who nonetheless is more or less unsatisfied with the authoritative system in question. Being

2 We shall confine the present discussion to this genre. Outside the genre, aporias played a central role in ancient and medieval-Arabic philosophy, which is of little relevance to our present purposes. For a broader discussion of aporias, see Rescher, Aporetics.

3 For a summary of the contents of Ibn al-Haytham's work, see Saliba, 'Arabic Planetary Theories', $75 \mathrm{ff}$.

4 See p. 23 above; al-Mas'ūdī, Kifāya, f. 124 ${ }^{\text {b; }}$ cf. Jahān-i dānish, 75-76. Ibn al-Haytham's treatise on winding motion is lost. He also wrote another work on the subject, in which he responded to problems raised by a contemporary against certain views of Ptolemy (published as Hall shukūk harakat al-iltifäf). On these works, see Sabra, 'Configuring the Universe', $298 \mathrm{ff}$.; Rashed, 'Celestial Kinematics', 9 ff. 
an insider, the author critiques the target system with a degree of precisionhence the appropriateness of the term shakk - and does not launch a sweeping attack that would threaten to demolish the field altogether. ${ }^{5}$ So he identifies problems and collates them in a dedicated work, which is then presented as a critique of the system as represented by the target sources. The objections can be minor, but they are often major and query fundamental theoretical principles of the system criticised. In some cases, the objector is motivated to raise his objections out of opposition to the views criticised, or to the broader system if the views in question are major or core components thereof. However, the problems raised can also be open-ended puzzles that are genuinely highlighted as being in need of resolution.

According to Abū Bakr al-Rāzī, objections can be addressed in either of two ways - this, he tells us, is how Galen, had he been alive, would have dealt with al-Rāzì's objections. ${ }^{6}$ The first is to advance a solution (hall) to the problem, which may refine the target system making it more robust and fortified than before. The second possible outcome is for the exponent of the target view to abandon (raja'a 'an) it, presumably in favour of a different view altogether. To this, we may add that a solution to the objection can be achieved in two ways: it can interpret the target text or view and thereby expose the objection as specious or off the mark, or it can resolve the problem by proposing an emendation or a supplement to the target system, without having to relinquish any of its defining premises.

As I have already suggested, the expression 'shakk' implies narrowness in the scope and implications of a criticism, and that when used to refer to the author's own arguments it accordingly implies that they are precise and made from an insider's perspective. In contrast, when used to designate objections raised by adversaries against views championed by the author, the label 'shakk' often acquires a negative sense, namely that the objections in question are insignificant or trivial. This, for instance, is the sense intended by Avicenna when he uses the expression to label arguments deployed by atomists against hylomorphism. ${ }^{7}$

5 This outlook is evident, for instance, in Ibn al-Haytham, Shukūk, 3-4. On account of the broad scope of the attack that al-Ghazālī deploys against Avicenna's metaphysics, the Tahäfut should be classed as a refutation, rather than an aporetic text (though it should be added that refutation texts are of different types and do not always involve the complete rejection of all views criticised).

6 Abū Bakr al-Rāzī, Shukūk, 40-41.

7 Avicenna, Țabīìyyāt, I.III.5, $302 \mathrm{ff}$. 
2. Exegetical Commentaries on Avicennan texts. Typically identified by the labels 'sharh' or sometimes 'tafsïr', exegetical commentaries constitute a distinct genre; and for a work to qualify as belonging to this genre it must provide substantial exposition of the text commented on, either in full or in part, though it may fulfil other functions over and above the purely expository. By the mid twelfth century, the tradition of commentaries on Avicennan texts was still very much in its nascence. There is evidence that the Ishärāt, which later became the centre of a long and venerable exegetical tradition, had already been attracting a good deal of interest, but by al-Mas'ūî̉'s time had yet to receive a fully fledged commentary. ${ }^{8}$ According to al-Rāzī, being a short and difficult text full of philosophical profundities, the Ishärāt challenged his contemporaries to understand its abstruse contents and to resolve the numerous philosophical and exegetical problems it raised, yet none succeeded in this endeavour. ${ }^{9}$ The only commentary known to have been written on the Ishärāt before al-Mas'ū $\mathbf{d}$ composed his $S h u k \bar{u} k$, or probably around the same time, is attributed to Zahīr al-Dīn al-Bayhaqī (d. 565/1170), though we have no extant copies of this work or information on how complete and substantial it was. ${ }^{10}$ In any case, al-Bayhaqi's commentary, to my knowledge, is never cited in later philosophical literature, and should not be credited with initiating the exegetical tradition on the Ishārāt. We also have Ibn Ghaylān's expression of intent to write a refutation (hence, not an exegetical commentary) of selected parts of the Ishārāt, to be titled al-Tanbīh 'alā tamwīhāt kitāb al-Tanbīhät (Drawing Attention to the Sophisms of the [Pointers and] Reminders), though it is unclear whether or not he did undertake this project. ${ }^{11}$ At any rate, the extant work titled Hudüth al-älam, in which Ibn Ghaylān announces these plans, post-dates the Shukük, so the Tanbih is likely to have been intended as a sequel to alMas'ūdī's work. ${ }^{12}$

As a distinct sub-class of exegetical commentaries, a small genre of counteraporetic texts emerged in parallel to aporetic texts. These super-commentaries generally offer 'solutions' (hall), or 'responses' (jawāb), which resolve problems raised in aporetic commentaries, either by exposing the objections as off-target, or through the expository reinterpretation of the main text, or by

\footnotetext{
8 On this, see Shihadeh, 'Al-Rāzī's Sharh', Section III.

9 Al-Rāzī, Sharḥ, 1, 2-3.

10 Yāqūt al-Ḥamawī, Mujam al-udabā', 4, 1763.

11 Ibn Ghaylān, Hudūth al-'ālam, 11; 128; Shihadeh, 'Post-Ghazālian Critic', 141.

12 As pointed out already, Ibn Ghaylān praises al-Mas'ūdī and cites his Shukūk (Hudūth al-'álam, 111; pp. 29-30 above).
} 
refining and developing aspects of the target system expounded therein. To all intents and purposes, therefore, the first of the long series of exegetical commentaries to be penned on the Ishārāt is al-Rāzì's Jawābāt, the counteraporetic super-commentary he wrote in response to al-Mas'ūdî's Shukūk, which is high on expository content. The Jawäbät can properly be termed a 'sharh'; and indeed, as I showed elsewhere, al-Rāzī himself refers to it simply as 'Sharh al-Ishäräat' in the Mabāhith, which predates his comprehensive commentary on the Ishärāt. ${ }^{13}$ The latter is, of course, the first major exegetical commentary to be written on Avicenna's text. ${ }^{14}$ In the same vein, Sayf al-Dīn al-Āmidī's Kashf al-tamwīhät fì sharh al-Tabīhät (Exposing the Sophisms in 'The Commentary on the [Pointers and] Reminders'), which responds to various contents of al-Rāzì's comprehensive commentary, especially its aporetic content, should be classed as an exegetical commentary (sharh). ${ }^{15}$

Earlier in the sixth/twelfth century, before the Ishärät became the focus of a commentarial tradition, two other general philosophical texts of Avicenna appear to have enjoyed this privilege. ${ }^{16}$ The text of choice for longer commentaries was the Najāt, which received at least two commentaries, namely a three-volume commentary by Zahīr al-Dīn al-Bayhaqī ${ }^{17}$ now lost, and one by a certain Fakhr al-Dīn Muḥammad ibn 'Alī ibn Abī Nașr al-Isfarāīnī al-Nīsābūrī, about whose life we know nothing though judging by the contents of the commentary he appears to have lived in the mid twelfth century. ${ }^{18}$ Al-Isfarā'in̄i's commentary survives in several manuscripts, and is largely expository. The

13 Shihadeh, 'Al-Rāzī's Response', 2; al-Rāzì, Mabāḥith, 1, 198.

14 On the structure and functions of this text, see Shihadeh, 'Al-Rāzī's Sharḥ'.

15 That said, much of al-Āmidī's commentary is only implicitly expository. It often defends and elaborates Avicenna's views without referring explicitly to the text of the Ishärāt.

16 Avicenna's medical Canon was commented on from the eleventh century. Apart from the two texts discussed above, two other philosophical texts received a small number of commentaries, but these were not general in their subject matter. Avicenna's Hayy ibn Yaqzān was commented on by each of his students Ibn Zayla and al-Jūzjānī (e.g. al-Bayhaqī, Tatimma, 99;100-101); and his Risālat al-Tayr was commented on by Ibn Sahlān al-Sāwī and Ẓahīr al-Dīn al-Bayhaqī (Yāqūt al-Hamawī, Mu jam al-udabā', 4, 1763).

17 Al-Bayhaqī, Tatimma, 16o; Yāqūt al-Hamawī, Mu jam al-udabā’, 4, 1763.

18 The metaphysical part of the latter work is published. Brockelmann wrongly attributes this work to Fakhr al-Dīn al-Rāzì, who never wrote a commentary on the Najāt (GAL Suppl. I, $815)$. One copy of this text, MS Istanbul, Köprülü, 89o, is attributed in the catalogue of the Köprülü collection to Abū 'Alī Muḥammad ibn 'Alī ibn Aḥmad ibn al-Ḥārithān al-Sarakhsī (d. 545/115o) (Şeşen, Fihris, 1, 439-440; on him, see al-Bayhaqī, Tatimma, 16o; al-Sam‘ānī, Tahbì $r, 2,175)$; however, the author's name is given in the body of the text as al-Isfarāīnī $\left(\right.$ f. $\left.1^{\mathrm{b}}\right)$. 
other Avicennan text that received commentaries is al-Khuța al-gharrä, a very short text of approximately 500 words. In 472/1079-1080, 'Umar al-Khayyām produced a short interpretive translation into Persian, and around the middle of the next century al-Mas'ū ī composed a more substantive, expository commentary on this work..$^{19}$ Interest in Avicenna's Khutba seems to persist until the late twelfth or early thirteenth century, as a further commentary is written by Muḥammad ibn 'Abd al-Wāhiid al-Tabrīzì (d. after 6o6/1210), a student of Fakhr al-Dīn al-Rāzī. ${ }^{20}$

\subsection{The Broad Outline}

As will become clear in what follows, although al-Mas'ūīis Shukūk is dedicated to a single Avicennan text, it is an aporetic commentary and not an exegetical one, and hence cannot properly be designated 'a sharh'. The book was intended by its author as an instalment in the shukūk genre, rather than a first attempt at a dedicated interpretive commentary on the Ishārāt. So even though alMas'üdì's book came to mark the genesis of the long exegetical tradition that grew around this Avicennan text, it is in fact generically at variance with the later tradition, including al-Rāzì's Jawābāt, as we have just explained. To my knowledge, it is the only aporetic commentary written on the Ishärāt..$^{21}$

\section{Preface and Conclusion}

In the preface and conclusion of the $S h u k u \bar{k}$, al-Mas'ū $\mathrm{u}$ in informs us of the book's objectives and modus operandi. The preface goes as follows:

These are puzzles (shukūk) and dubitations (shubah) that I encountered ('aradat lī) in some places in the Ishärāt. I have not lost hope of solving

\footnotetext{
19 Al-Khayyām, Tarjama, 228. Avicenna's text is also briefly cited by al-Rāzī (Mabāhith, 2, 501 ).

20 This work is extant in several manuscript copies, for instance, MS Istanbul, Mehmed Asım Bey 238 (Şeşen, Fihris, 3, 108). Al-Tabrīzì does not seem to refer to al-Mas'ūdī's commentary.

21 So the other commentaries, including the 'adjudication' (muhākamāt) series of commentaries, are exegetical, although some include aporetic content, such as al-Rāzīs Sharh. Zayn al-Dīn Ṣadaqa's (d. Before 678/1279) Sharh Masāill 'awīṣa fì l-Ishārāt (Explicating Some Knotty Problems in 'The Pointers') seems to be an exegetical commentary, as the commentator is concerned mainly with explaining and developing Avicenna's views and arguments, rather than bringing them into question. For Șadaqa's death date, see Wisnovsky, 'Avicennism and Exegetical Practice', 353.
} 
(hall) them; for 'on certain days God bestows favours'.22 So I have committed them to writing to keep them from slipping away. I have also complemented them with what I myself have established and arrived at through my own research (intahà ilay-hi bahthth-i) into some problems. I ask God, exalted, to illuminate our insight by guiding us to truth, and to prevent us from falsehood and error. [The Prophet], may God's peace be upon him, used to pray, 'Our Lord, make plain to us things as they truly are, and make plain to us the truth of the true and guide us to follow it, and the falsity of the false and guide us to eschew it!' I have presented these puzzles to the most excellent of my contemporaries, so that they may assist me with some of their burden $\left(a^{c} b \bar{a}^{3}\right)$. For the traveller on a journey may need the guidance and company [of fellow travellers]. ${ }^{23}$

The book concludes thus:

These are some of the puzzles that I have been turning over in my mind. In addition to these, I have remarks on further discussions [in the Ishārāt], which can be construed as secondary problems $\left(f u r \bar{u}^{c}\right)$ based on primary problems that we have discussed, such as the proving of intellects and souls on the basis of both the manner in which things proceed from the First Principle and [the doctrine] that from one only one thing proceeds, and the like. To the extent that the primary doctrines are sound, secondary ones will follow from them. For this reason, I have decided to neglect [these secondary doctrines], considering that there is little value in [pursuing] them. God guides and leads us to what is true and correct. May the mercy of God be upon those who read [this book of mine] in a spirit of impartiality (bi-'ayn al-inșāf), who give their attention to the discussion rather than the discussant, and who renounce prejudice and partisanship (al-mayl wa-l-așabiyya) so as to seek truth immune from their influence. We rely on God's favour to open before us the gates of certainty, to illuminate our hearts with the lights of knowledge, to remove affliction, to eliminate dubitations (shubah), and to make plain to us the truth of the true and the falsity of the false! $!^{24}$

Echoing part of a hadīth: 'inna li-rabbi-kum fì ayyām dahri-kum nafahāt' (on this hadīth, see, for instance, al-Zabīìi, Ithăf $f$, 3, 280-281).

23 Shukūk, 196.

24 Shukūk, 288.
} 
Several important points are made in these two passages. As always, however, we must exercise due caution with the author's own claims of what he does and achieves in his book; so these points need not be taken entirely at face value.

Al-Mas' ūdī, first of all, declares that the principal purpose of the book is to record 'puzzles' and 'dubitations' that he 'encountered' in the Ishärāt. The commentator's choice of the verb 'encountered' is noteworthy, as it suggests that he did not read the Ishārāt intent on finding faults in the text and thereby refuting its author's views, but that he merely stumbled across them while closely studying Avicenna's book. The expression shubha, which occurs in the preface and conclusion and is rendered here as 'dubitation', does not seem to be used in a very precise sense, but is likely intended as a synonym of shakk.

These problems, as we also learn from the preface, need to be 'solved', and as such they constitute a 'burden' on our commentator. Their burdensome nature implies that some, or all, still await to be solved. Al-Mas'ūdì has thus been 'turning the problems over in his mind', and 'has not lost hope' that one day — with God's help, as he tells us — he will solve them. Feeling that he would do with some human assistance too, he recorded these problems and circulated them to some learned contemporaries, in the hope that they would be able to 'share some of the burden' and offer assistance towards solving them. Al-Rāzī takes up the invitation: in the preface to the Jawäbät, he tells us how the Shukük was presented to him by an unidentified individual, who asked him 'to wade into the oceans of these problems, and to solve the difficulties posed by these knotty puzzles (mu'dilāt $)^{\prime} .25$

Thus far, one gets the impression that al-Mas'ūdì's stance towards Avicenna is rather benign. He does not go out of his way to dig up problems in Avicenna's philosophical system, or to construct objections to it, but supposedly stumbles upon some problems almost by accident. He feels burdened by the problems he has identified, and spares no effort to solve them. As we have already seen, the objection (shakk) and solution (hall), which often come as a pair, are normally undertaken by two different individuals, one who raises the objections and another who responds to them and defends or develops the system criticised. Al-Mas'ū $\bar{d}$ does the former, and expresses his desire and hope to do the latter. And, as noted, a 'solution', properly speaking, should not deviate radically from the target system, but should be conducted as much as possible within its parameters.

25 Al-Rāzī, Jawābāt, 11. 
Notwithstanding, al-Mas'ūdī also informs us in the preface that he has complemented his discussion of some of the problems identified in the Ishärāt with the results of his 'own research' (bahth). As we shall see, the majority of the problems are indeed presented, not merely as puzzles that need solving, but rather as objections to Avicennan views, coupled with more positive investigations in which the commentator submits and defends views of his own, which are contrary to Avicennan positions. This dual function of the commentary is reflected in its title, al-Mabāhith wa-l-shukük (Investigations and Objections)the expression 'mabhath' here denotes the treatment of a philosophical problem (mas'ala) through productive research (bahth), as opposed to unconstructive criticism. At first glance, these positive contributions appear to be attempts by the commentator to 'solve' some of the problems he raises. However, in all or most cases, they certainly are not solutions; and indeed they are never presented as such. For, as I shall explain shortly, al-Mas'ūdī's objections often target quite fundamental and defining doctrines of Avicennan philosophy, and the corresponding alternative views he proposes are profoundly incompatible with it.

For solutions to most of al-Mas'ūdī's objections, we must turn to al-Rāzì's Jawābāt. Although he titles his work using the more common expression 'response' (jawāb), al-Rāzì writes in the preface that his task will be 'to wade into the oceans of these problems, and to solve (ahulla) the difficulties posed by these knotty puzzles'. ${ }^{26}$ The conventional expression 'solution' (hall) is accordingly used at several points within the text. In the Mabāhith, he also speaks of 'solving' the objection quoted from the Shukūk. ${ }^{27}$

A further key point made in the conclusion of the Shukūk is that al-Mas'üdī indicates his commitment to the ideal of dispassionate philosophical enquiry. Conscious that the debate between traditional Avicennists and critics of Avicenna has often been hostile, and that his work may be construed as an episode in an ongoing onslaught on Avicennan philosophy, he is keen to dispel this notion. He encourages his readers to direct their attention to the contents of the text and not to the author, and to abstain from 'prejudice and partisanship' (al-maylwa-l-așabiyya) and be impartial (inșăf) in their assessment of his ideas. The same point is echoed twice in the body of the book, where it is stated that one who refrains from prejudice and partisanship and weighs the problems under discussion fairly will realise that the author's views are correct. ${ }^{28}$

\footnotetext{
26 Al-Rāzī, Jawābāat, 11; cf. 15; 31; 35.

27 Al-Rāzī, Mabāḥith, 2, 317; see p. 4, n. 14, above.

28 Shukük, 215-270.
} 
By implication, al-Mas'ū $\bar{d}$ himself adheres to the same attitude in the Shukūk. And we have already seen him, in a prefatory proviso in his commentary on al-Khuțba al-gharrä', explicitly declare his commitment, in precisely the same terms, to eschew 'prejudice and partisanship' while treating Avicenna's ideas. ${ }^{29}$ In the Shukūk too, he is careful not to appear motivated by either partisan, anti-Avicennan prejudice or the desire to defend a competing thought or belief system.

\section{Structure}

The Shukūk consists of fifteen sections, whose contents we shall overview in the next section. In the body of the text, each is headed 'problem' (mas'ala) and given an ordinal number. The two earliest manuscript copies are furnished with a prefatory table of contents in which substantive section headings are provided, and which in all likelihood originates with the author. ${ }^{30}$ The sections are of varying length, the longest being Section 4, and the shortest Sections 15 and 6.

From what al-Mas'ūdī tells us in the conclusion, the Shukūk contains only some of the problems that he identified in the Ishärāt. The selection of which topics to include and which to leave out, and hence which passages from the Ishārāt to comment on, is determined, to an extent, by the distinction he makes between foundational, 'primary doctrines', or 'principles', $(u s \underline{u} l)$ and 'secondary doctrines' $(f u r \bar{u})$, that is, doctrines grounded in primary ones. ${ }^{31}$ This distinction is applied widely in kaläm and jurisprudence, and much less so in philosophy. We have already seen the former term used in Sharh al-Khuṭba, where two theories are described as 'principal doctrines' (așl kabir) of Avicennan philosophy, or more specifically, of Avicenna's theory of emanation, on which many secondary doctrines are premised-namely, the doctrine of atemporal creation and the doctrine that from a cause that is absolutely one only one effect proceeds. ${ }^{32}$ As al-Mas'ūdī indicates, some secondary problems are left out because the primary problems on which they are based have already been treated in the book. He gives the example of the theory of the celestial souls and

\footnotetext{
29 See p. 21 above.

30 See pp. 169-172 below.

31 Shukūk, 288.

32 See pp. 37 and 40 above. He writes concerning the latter: 'This is one of the principal doctrines of the philosophers, and a foundational problem on which numerous secondary doctrines are based (min ummahāt al-masā̉il yanban̄ 'alay-hā furū' kathīra)' (Sharh alKhuṭba, f. $41^{\mathrm{a}}$ ).
} 
Shukūk

Establishing the existence of matter

2. Establishing the finitude of bodies

3. That the power that preserves the mixture is the soul

4. The reality of perceptions, and the external and internal senses

5. That the rational soul is not imprinted in the body

6. That some existents are beyond the grasp of the senses

7. Establishing the existence of the Necessary of Existence and the finitude of causes

8. Establishing the oneness of the Necessary of Existence

9. That the continued existence of the effect depends on the continued existence of its cause

10. That the possibility of coming-to-be is an attribute that exists prior to coming-to-be

11. That from one only one effect can proceed

12. That the activities of corporeal powers are finite

13. That the human soul is not affected by the loss of the body through death

14. That the human soul cannot possibly pass away

15. [The knowledge that the Necessary of Existence has of Itself and of things other than Itself]
Ishārāt:

Lemmata $^{34}$

$1.6(2,168-173)$

$1.10(2,182-183)$

$1.11(2,183-190)$

$3 \cdot 5^{-6}\left(2,35^{-}-357\right)$

$3 \cdot 7(2,359-366)$

$3 \cdot 9(2,373-376)$

$3.13(2,396-398)$

$3.16(2,404-408)$

$7 \cdot 2-5(3$,

244-26o)

$4.1(3,7-9)$

$4.12(3,23-24)$

\section{Citations}

$$
\begin{array}{ll}
4.18(3,36-41) & 4.21-22(3,44-46) \\
4.10(3,20) & 5.1-3(3,57-70)
\end{array}
$$

$5.6(3,78-84)$

$5.11(3,97-102)$

$6.19\left(3,165^{-169)}\right.$

$6.23(3,172-174)$

$7.2(3,244-248)$

$7.2-4(3,249-252)$

$7.6(3,261-264)$

$7.15(3,278)$

$7.21\left(3,295^{-296)}\right.$

33 For the Arabic table of contents, see p. 195 below.

34 All references here are to Part II of the Ishärāt. 
intellects, premised on both the theory of how things proceed from the First Principle (which seems to involve several sub-theories), and the principle that from an absolutely simple cause only one effect can proceed. These two underpinnings are treated, respectively, in Sections 9 and 10, and in Section 11 of the Shukūk, and, as it happens, they correspond to the two theories described in Sharh al-Khutba as 'principal doctrines' of Avicennan philosophy. ${ }^{35}$ The point made in the conclusion of the Shukük concerning the selection of problems is confirmed, or probably echoed, in the preface to al-Rāzì's Jawābāt, where he writes that the author of the Shukūk 'selected, out of [the problems of] philosophy, those that are primary, principal, foundational and important (al-ușūl wa-l-ummahāt wa-l-qawā id wa-l-muhimmāt)', ${ }^{36}$ That said, al-Mas'ūīi does not claim that all the problems treated in the book are 'primary'. Some are ones that he would certainly class as 'secondary', a case in point being Section 14, in which the commentary starts with the remark that Avicenna 'based this on an aforementioned principle', which was treated in Section 10. ${ }^{37}$ Likewise, Section 5 presupposes and references Section $4 .{ }^{38}$

The sectional commentaries do not have a fixed internal structure. Unlike al-Rāzì's Sharh on the Ishārāt, which owes its elaborate structure to its being a systematic and multifunctional exegetical commentary, al-Mas'ūdī's work is a much simpler, mono-functional aporetic commentary. ${ }^{39}$ Each discussion is hence conducted on an ad hoc basis, depending on the nature of the objection raised on the Avicennan text. The structural simplicity of sectional commentaries, of course, also reflects the fact that the Shukūk was breaking new ground, and was not part of a developed commentarial tradition, with established conventions, structures and debates. The following elements can be identified in sectional commentaries:

1. A passage from the Ishärāt. Each section begins, of course, by quoting a passage from the Ishārāt, introduced by, 'Al-Shaykh Abū 'Alī says' (qāla), or 'He, may the mercy of God be upon him, says'. This is followed by commentary, introduced by, 'I say' (qultu or aqūlu). Further passages from the Ishārāt are occasionally cited either at the beginning, or in the course, of the commentary, in order to explain the contents and objectives of the main passage

35 See pp. 37-40 above.

36 Al-Rāzī, Jawābāt, 11.

37 Shukūk, 285. See also our study of Section 14, pp. 136-141 below.

38 Shukūk, 240.

39 On the structure of al-Rāzì's commentary, see Shihadeh, 'Al-Rāzì's Sharḥ'. 
cited, or to bring into the discussion further aspects or details of the Avicennan views under consideration. Most passages from the Ishärāt are cited in their entirety, but others, especially supplementary passages appearing within sectional commentaries, are often cited partially and appended with 'et cetera' (ilä $\bar{a} k$ hiri-hi). The table on p. 54 lists all the Avicennan passages commented on or cited. No other Avicennan works are referenced in the Shukūk.

2. Expository interpretation. As to be expected of an aporetic commentary, the Shukük gives relatively little space to the expository interpretation of the main text, which, by contrast, is a principal function of an exegetical commentary. The preface, as we have seen, does not mention expository interpretation among the book's objectives; and nowhere in the book is the commentary described using such terms as 'sharh' or 'tafsir'. The commentator appears to assume that most passages commented on from the Ishärät will be understood by his readers with minimal interpretation. So he does not seem to regard the little expository content of his commentary as especially original or illuminating, despite its admirable lucidity. For example, he describes the longest instance of expository interpretation, which occurs in Section 4, merely as a 'report' of 'what the majority [of philosophers] have agreed upon'-so it is only a report (hikāya) and a summary, rather than an original and thoroughgoing exposition..$^{40}$ An exception is the interpretation provided at the start of Section 8, which offers a tidy and creative reading of a rather fraught passage from the Ishārāt, as we shall see. ${ }^{41}$ In most sections (specifically, Sections $1,5,6,7,9,10,11$ and 13), the commentary begins with a very brief explanation of Avicenna's text, sometimes introduced by 'his objective is' (gharad, maqșūd, arāda an), which either clarifies the contents of the main text, or provides an indication of their wider context. Sections 2 and 3 contain no expository commentary at all. Other sections (specifically, Sections 4, 8, 12 and 14) start with a relatively longer, but not extensive, expository commentary.

3. Objections and puzzles. These, of course, are the principal elements of the commentary. Despite the appearance of the expressions 'shakk' and 'shubha', both in the plural, in the book's preface and conclusion (and in the case of the former expression, in the title), neither expression is ever used within the sectional commentaries themselves, except in Section 15 where 'shukūk' refers

40 Shukūk, 212.

41 See pp. 69-70 below. 
to al-Ghazāli’s objections against certain Avicennan views. In the course of the commentary, al-Mas'ūdì sometimes refers to the objections he raises using the term 'ishkāl' (problem), which more or less has the same sense as 'shakk' ${ }^{42}$ He twice describes them as 'objections' (itirāạd). ${ }^{43}$ In al-Rāzìs Jawābāt, this expression becomes the standard characterisation of the problems raised in the $S h u k \bar{u} k$, and al-Mas'ūdī is referred to constantly as 'the esteemed objector' (al-fädil al-mu'tarid $).{ }^{44}$ Other markers are employed in the Shukük to signpost criticisms, such as 'one may argue' (li-qā̉il an yaqūla) (in Sections 1 and 2), ${ }^{45}$ 'this [i.e. an Avicennan view] is open to question' ( fi-hi nazar) (in Sections 3 and 8), ${ }^{46}$ and 'this [i.e. an Avicennan argument] falls short of its intended objective' (e.g. lā yafì bi-hādhā l-gharad, lā yufidu hādhā l-mațlūb) (in Sections 1,6 and 10). ${ }^{47}$ Some objections, however, are not marked so clearly. After an objection is submitted, the ensuing discussion sometimes proceeds in the question-and-answer dialectical mode characteristic of kalām: 'If it is said ...' (in qüla, in qultum, in qālü), 'we will say ...' (qulnā), or 'the response is ...' (al-jawāb).

4. Alternative views and arguments. As well as criticising Avicenna's doctrines and arguments, al-Mas'ūdī, in some sections, submits and defends his own alternative theses concerning the problems under discussion. Some are fully fledged theories, explained and argued in detail, as, for instance, is the case in Sections 1 and 10 discussed below. ${ }^{48}$ These are sometimes marked by expressions that indicate positive 'investigation' aiming at knowledge of reality, as opposed to the raising of objections against someone else's thought systemmost importantly, 'critical investigation' (tahqiq ), 'research' (bahth), 'bringing to light' (kashf) and 'reflection' (nazar). ${ }^{49}$ For instance, in one discussion, al-

\footnotetext{
42 Shukük, 204; 228; 273; 275; 280; 282; 286; 287.

43 Shukūk, 253; 260.

44 Al-Rāzī, Jawābāt, passim. In the preface, he describes the contents of the Shukūk as 'investigations and objections' (abhäth wa-i'tirādāt) (Jawābāt, 11). He sometimes refers to al-Mas'ūdī's objections using the expression 'ishkāl' (e.g. Jawābāt, 15; 43; 51).

45 Shukūk, 197; 205. This phrase becomes al-Rāzīs standard marker for his own objections to Avicenna's views in his commentary on the Ishärāt (Shihadeh, 'Al-Rāzī’s Sharh').

46 Shukūk, 205; 252.

47 Shukūk, 197; 246; 240.

48 See Chapters 4 and 6 below.

49 Shukūk, 199; 212; 250. Though there are occasional exceptions, the expression 'tahqīq' should not be rendered as 'verification', as has become the norm in recent studies. Such a rendering, first of all, is a mistranslation: 'to verify/verification' correspond to 'tahaqqaqa/
} 
Mas'ūdì's own position is introduced as 'what [we] have arrived at through [our] research and investigation' (alladhì intahä ilay-hi l-bahth wa-l-nazar)..$^{50}$ In other discussions, the alternative view or argument is submitted tentatively as a hypothesis, with little or no substantiation. For instance, in Section 11 an Avicennan theory is criticised, and at the very end of the section an alternative theory is briefly proposed as a possibility that is at least as compelling as the theory criticised. ${ }^{51}$ In Section 2, an Avicennan proof is confuted; and although an improved proof is proposed, in the end it is pronounced unsound on exactly the same grounds. ${ }^{52}$

As already noted, these elements do not appear in a fixed order within the sectional commentaries of the $S h u k \bar{u} k$; and this fact, particularly the relative ordering of objections and alternative views, drew sharp criticism from al-Rāzī. In some discussions, as for instance in Section 1, al-Mas'ūdī criticises Avicenna's views first, before going on to submit his own thesis. ${ }^{53}$ Elsewhere, the thesis comes before the complaint, as for instance in Section 4, where alMas'ūdī proceeds by summarising the Avicennan theory of perception and then writes, 'What we have just reported $(h a k \bar{a})$ is what the majority have agreed upon. As to what [we] have arrived at through [our] research and investigation ....54 He then summarises his own alternative theory, which draws on Abū l-Barakāt, and follows that with arguments against Avicenna's position and in support of his own. Al-Rāzī disapproves of this procedure, as he remarks in the Jawābāt:

This esteemed [objector] ought to start by objecting to the arguments he cites from the Ishārāt and only then proceed to set out his own position.

tahaqquq (min)', and not to 'haqqaqa/tahqīq'. What 'tahqīq' means is simply to arrive at knowledge of some truth or reality (haqq, haqiqa), as opposed, for instance, to accepting a doctrine more or less uncritically ( taqlìd) or to engaging merely in the discussion, criticism or refutation of some doctrine or other. To arrive at knowledge, one should investigate (bahth, nazar) thoroughly and critically using valid means and sound premises. In theory, the investigation of a problem should start with an open mind, and not from a view that the investigator then seeks to verify. A good investigator should ask, 'Who among these suspects is guilty?', rather than start, for some reason or other, with a presumption of the guilt of Zayd and then seek to verify it.

5o Shukūk, 212.

51 Shukūk, 277-278.

52 Shukūk, 203-204.

53 Shukūk, 199.

54 Shukūk, 212. 
For it is insufficient for one who goes against the majority (jumhūr) view on a certain point [simply] to set out his own view. Instead, he should [first] confute the arguments of [his] predecessors and identify any weakness or error in the premises of these arguments. ${ }^{55}$

Elsewhere in the Jawābāt, al-Rāzì complains against the relative organisation, not only of the objections and alternative theses, but also of the brief expository interpretation of Avicenna's views. He remarks on Section 3 of the Shukūk:

This discussion, in my view, is unbefitting of its writer's sharpness of thought and his in-depth study of tortuous philosophical subjects; and this is in two ways. The first is that one who advances a certain view, and then raises a question concerning it, must answer it in such a way that his first view remains intact. However, if in his answer he advances a new view, which is unrelated to his first view, this will amount to an admission that the first view is weak and unsustainable. ${ }^{56}$

Al-Rāzī goes on to explain that this is exactly what al-Mas'ūdī does in Section 3: (1) al-Mas'ūdī starts by accusing Avicenna of circularity for suggesting that the rational soul of the foetus combines the mixture of its body, although its rational soul requires a suitably prepared body before it comes to be; (2) he does not report Avicenna's view, put forth in the Mubāhathāt, that the mixture of the foetus's body is initially combined by the souls of its parents; (3) yet he then considers the possibility that the mixture of the foetus's body be initially combined by the souls of its parents, which is introduced with, 'if it is said' ( $f a$-in qīla). According to al-Rāzī, the last step in al-Mas'ūdì's discussion renders the first step superfluous, and exposes it as based on a misinterpretation of Avicenna. ${ }^{57}$

\subsection{A Synopsis}

What follows here is a section-by-section overview of the contents of the Shukūk, exploring the Avicennan views and arguments discussed and al-

\footnotetext{
55 Al-Rāzī, Jawābāt, 33; Shihadeh, 'Al-Rāzī’s Response', 6.

$5^{6}$ Al-Rāzī, Jawābāt, 29.

57 See p. 62 below; Shihadeh, 'Al-Rāzī's Response', 6.
} 
Mas'üdī's main criticisms. A more thorough analysis and contextualisation of some discussions is provided in Chapters $3^{-6}$, but will not be attempted in the present section.

\section{Section 1. Establishing the Existence of Matter}

Discussed in Chapter 6. In Ishärāt II.1.6, Avicenna proves the existence of prime matter starting from body's susceptibility to division. ${ }^{58}$ Body is continuous, but also divisible. So it has actual continuity, and at the same time the potentiality for discontinuity, which is the contrary of continuity. Therefore, body is a complex of two principles: one which provides its actual continuity, and another which provides its potentiality for discontinuity. The former is corporeal form, and the latter is prime matter, which of itself lacks continuity and extension.

Al-Mas'ūdì objects to the claim that when body is divided, substantial continuity passes away. ${ }^{59}$ What is lost with division, he argues, is continuity as an accident in the category of continuous quantity, whose subject is body. Corporeity, on the other hand, does not change, as the parts that result from dividing a body are no less corporeal than the original body. Therefore, Avicenna's argument fails to demonstrate that body consists of prime matter and form.

The section concludes with a defence of an alternative hylomorphic theory, according to which prime matter is corporeal and hence none other than body. ${ }^{60} \mathrm{Al}-\mathrm{Mas}$ ' ūdī supports this theory by arguing that when a body undergoes change in its species form, one essence passes away and another comes to be, yet something remains unchanged in the body, neither passing away nor coming to be. So body is a complex of two principles: form, whose passing away and coming to be accounts for the change, and prime matter, which remains unaltered. Al-Rāzì observes that both al-Mas'ūdī's objection and theory of matter are borrowed from Abū l-Barakāt. ${ }^{61}$

\section{Section 2. Establishing the Finitude of Bodies}

In an almost impenetrable passage, Ishārāt II.1.11, Avicenna provides a geometrical reductio ad absurdum to establish the finitude of space, which can be

$5^{8}$ Avicenna, Ishārāt, 2, 168-173; cf. Shihadeh, 'Avicenna's Corporeal Form and Proof of Prime Matter', 370-378.

59 Shukūk, 197-199.

6o Shukūk, 199-200.

61 See Section 6.4 below. 
summarised as follows. ${ }^{62}$ If we postulate two lines that share the same starting point $A$, and are each infinite in one direction, we can postulate a third line starting from a given point $B_{1}$ on one of the two lines, and ending at point $C_{1}$ on the other line, where $B_{1}$ and $C_{1}$ are equidistant to $A$. We may then postulate further lines connecting the two lines starting from $A\left(B_{2} C_{2}, B_{3} C_{3}\right.$, etc.), which run parallel to the line $B_{1} C_{1}$ and increase in length at fixed increments (and hence, with each increment, become increasingly distant from A). Now, either there is a line $B_{n} C_{n}$, which contains all increments and beyond which no further increments are possible, or there is no such line. The former contradicts our initial postulate that the two lines starting from $A$ are infinite; for lines $A_{n}$ and $\mathrm{AC}_{\mathrm{n}}$ must be finite. The latter implies that there is an infinite line $\mathrm{B}_{\infty} \mathrm{C}_{\infty}$ that is bounded by the two lines starting from A. However, being at once infinite and bounded is a contradiction. Therefore, the initial assumption that the two lines starting from A are infinite is false; and it follows that they must be finite.

Al-Mas' ūdī objects that if we postulate that the lines $\left(\mathrm{B}_{2} \mathrm{C}_{2}, \mathrm{~B}_{3} \mathrm{C}_{3}\right.$, etc.) increment in length ad infinitum, it does not follow that there must be a line that contains all increments and beyond which no further increments are possible. ${ }^{63}$ Indeed it is impossible to postulate an individual line that contains an infinite number of equal increments of length; for whatever line we postulate, there will be a line longer than it. Therefore, no absurdity follows from the postulate that the two lines starting from A are infinite.

At the end of the section, al-Mas'ūdī proposes an alternative reductio, which he describes as simpler and shorter than Avicenna's. It runs as follows. ${ }^{64}$ If we postulate the two lines starting from $A$ forming an obtuse angle with each other, and if we then take any point $B$ on the first line and any point $C$ on the second line, the line $\mathrm{BC}$ will be longer than either $\mathrm{AB}$ or $\mathrm{AC}$. Then if we assume that each of $A B$ and $A C$ is infinite, line $B C$, which is the longest line of the three, must also be infinite. So line $\mathrm{BC}$ will be infinite, yet at the same time bounded by two points on two other lines, which is a contradiction. Al-Mas'ūdī, nonetheless, remarks that this improved proof is susceptible to the same objection raised against Avicenna's proof. In his Jawābāt, al-Rāzì says that a similar argument was put forth in an unidentified work by Rashīd al-Dīn Wațwāț but he stops short of asserting that al-Mas'ū ui borrowed it from him. ${ }^{65}$

62 Avicenna, Ishārāt, 2, 183-190. See also al-Rāzìs lengthy interpretation of the passage (Sharh, 2, 47-54).

63 Shukūk, 201-202.

64 Shukūk, 203-204.

65 Al-Rāzì, Jawābāt, 26. 


\section{Section 3. That the Power That Preserves the Mixture is the Soul}

In Ishärät II.3.5, Avicenna argues that the soul is different from either the corporeity or mixture (or temperament, mizāj) of the human body, starting from evidence of the soul's activity in the body. ${ }^{66}$ The body moves in a manner different from the motion that its mixture inclines towards by its nature, and it perceives things by which the mixture either would not be affected (because they are identical to it in kind), or would be transmuted (because they are contrary to it). Therefore, there must be something other than the mixture that explains bodily movement and perception. What is more, the mixture of the body consists of contrary elements that are naturally predisposed to separate from each other. So there must be a force that causes them to combine (jama'a) and mix and then preserves (hafiza) their combination; and this force cannot be an activity of the mixture itself, since it causes the mixture's coming-to-be and hence precedes it. Therefore, it must be an activity of the human soul.

Al-Mas'ūdī complains that the human soul cannot cause the combination of the mixture, since the soul only comes to be once there is complete preparedness (tamām al-isti'dād) for its coming-to-be, which consists of a fully formed human body possessed of a balanced mixture. ${ }^{67}$ So the human soul comes to be after the coming-to-be of the mixture. Notwithstanding, al-Mas'ūdī agrees that the mixture of the body is combined and preserved by a soul, but he argues that this must be the vegetative soul, rather than the rational soul. The vegetative soul, as he goes on to elaborate in some detail, comes about in the human body before the rational soul comes to pass, and it is its activity that explains the growth and nutrition of the foetus, and hence the development and preservation of its mixture. At the end of the section, al-Mas'ūdī concedes the possibility that the foetus is managed by the vegetative and animal soul of its mother, though he does not explain the role of her animal soul in the process. ${ }^{68}$

66 Avicenna, Ishārāt, 2, 350-355.

67 Shukūk, 205-206.

68 As al-Rāzī (Jawābāt, 27-28) points out, Avicenna maintains in the Mubāhathāt (123; 169-170) that the mixture of the foetus's body is combined by the souls of its parents. Al-Ṭusī (Hall, 2, 355-356) cites the Psychology of the Shifä’ (Nafs, 31), where Avicenna asserts that the foetus's soul is what combines the mixture of its body. This question goes beyond our present purposes. 


\section{Section 4. The Reality of Perceptions, and the External and Internal Senses}

The longest section in the $S h u k \bar{u} k$, Section 4 delivers an extensive rebuttal of Avicenna's theory of perception, especially sensory perception, and advocates a radically different theory ${ }^{69} \mathrm{I}$ argue in the next section that this discussion may have an indirect and unstated theological objective. The main thrust of al-Mas'ūdī's criticism appears twofold: first, Avicenna constructs a modular, and hence fragmentary psychology, which assigns sensory activities to discrete external and internal senses, and intellection to the rational soul; and second, it collapses the process of sensory perception into the senses, which are made both the perceivers and strictly speaking the locations of perceptible objects. In doing so, Avicenna creates a gulf between the rational soul and objects of perception in the extra-mental world. Under the influence of Abū l-Barakāt, al-

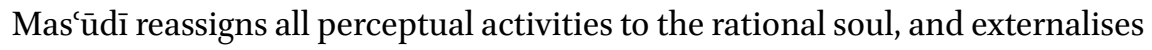
the process of perception, such that objects are perceived in the extra-mental world.

Taking his cue from Ishārāt II.3.7 and II.3.13, al-Mas'ūdī begins with a lucid enunciation of the Avicennan account of sensory and intellectual perception. ${ }^{70}$ According to Avicenna, we are told, perception occurs when the perceiver comes into contact (mulāqāt) with the object of perception, such that the former becomes imprinted (irtisām) with a representation (mithāl) of the latter. Faculties of perception divide into bodily and non-bodily ones. The non-bodily perceiver in the human being is the rational soul, which has the capacity for intellection; and its objects of perception are both universals, which are perceived when their forms obtain and become imprinted in the rational soul, and incorporeal particular entities. The external and internal senses, which exist in the body, perceive both corporeal things and imaginations. An external object is perceived when the perceiving faculty is imprinted with a representation of the object, which occurs when the sense organ, in which the faculty is present and which it uses as its instrument, comes into contact with the external object and becomes affected by it. The sense organ, accordingly, becomes the meeting place for the faculty and the representation. Avicenna explains all types of

69 I explored this discussion and its wider context in an unpublished paper titled 'Theories of Perception in Twelfth Century Post-Avicennan Philosophy', which was presented at 'In the Age of Averroes: Arabic Thought at the End of the Classical Period, a conference held at the Warburg Institute on 14-16 February 2008.

Avicenna, Ishārāt, 2, 359-366; 2, 396-398; Shukūk, 209-212. On Avicenna's theory of perception, see, for instance, Sebti, 'Le Statut Ontologique de l'Image'; McGinnis, Avicenna, 96 ff.; Kukkonen, 'Faculties in Arabic Philosophy'. 
perception in this way, which is why, for instance, he defends an intromission theory of visual perception, according to which vision occurs when external objects become imprinted in the eye. ${ }^{71}$

Countering this theory of perception, which, al-Mas'ūdī says, was accepted by the majority (al-aktharūn, al-jumhür) of his contemporaries, our commentator defends and develops two theses advocated by Abū l-Barakāt. ${ }^{72}$ The first is the theory that perception should be conceived not as contact between the perceiver and the object of perception, but rather as a state that the perceiver has in relation (hâla iḍaffiyya) to the perceived object. ${ }^{73}$ Al-Mas'ūdì substantiates this view with several arguments. For instance, I can perceive myself; however, self-perception cannot possibly involve the representation of oneself within oneself, so perception is not the representation of the perceived in the perceiver. A discussion of a possible response ensues. ${ }^{74}$

The second thesis adopted from Abū l-Barakāt is that the sole perceiver of all types of perception, including the intellectual perception of intelligibles and the sensory perception of particulars, is the rational soul. ${ }^{75} \mathrm{Al}-\mathrm{Mas}$ 'ùdì argues that if intelligibles are perceived by one part of the human being (the rational soul) and particulars by a different part (the faculties in the body, using bodily organs), the individual would consist of two perceivers, rather than be one perceiver, as is obviously and unquestionably the case. So the rational soul perceives intelligibles in itself, and perceives sensibles using the sense organs as instruments. However, it may be argued, in defence of Avicenna's theory of perception, that it does not entail a duality of perceivers within the human individual, because the sensory faculty perceives an external object and then passes on the content of its perception to the rational soul, which becomes aware of it. Al-Mas'ūdī asks in response whether or not the soul, on this model, will perceive the perceptual content conveyed to it. If it perceives it, then the function of the sensory faculty is not to perceive, but only to pass on some content to the soul. If the soul does not perceive the content, then it will merely be aware that a certain faculty perceived something; and it follows that I should not know what my eyes and ears perceive.

\footnotetext{
71 Shukūk, 211-212. On Avicenna's theory of vision, see Hasse, Avicenna's De anima, $107 \mathrm{ff}$;; McGinnis, Avicenna, $102 \mathrm{ff}$.

72 Abū l-Barakāt, Mu'tabar, 2, 394ff. For a discussion, see Pines, 'La Conception de la Conscience de Soi'.

73 Shukūk, 212.

74 Shukūk, 212-215.

75 Shukūk, 215-217.
} 
As an application of this theory of perception, and again drawing partly on Abū l-Barakāt, al-Mas'ūdī then defends at length an extramission theory of vision and attacks Avicenna's intromission theory. ${ }^{76}$ Part of this discussion is quoted in al-Rāzì's al-Mabāhith al-mashriqiyya. ${ }^{77}$ Al-Mas'ū ūi argues, for instance, that if vision occurs when the image of an external object becomes imprinted in the eye and is then passed on to the brain, then the image would be extremely small; so we should perceive a mountain as a miniscule object no larger in magnitude than its representation in our brain. ${ }^{78}$ However, we perceive not only the shape and colours of a mountain, but also its magnitude; therefore, what we perceive is the mountain itself, rather than its replica in our eyes or brain. The reality of vision, al-Mas'ūdì explains, consists of the soul's awareness of the visual object through the mediation of specific instruments, which in the first instance are the eye, the pneuma existing therein, and the luminosity (nür al-'ayn) that is an accident that inheres in the pneuma. Vision, nonetheless, does not involve the emission of a ray from the eye towards the visual object, but occurs rather when the cone of air separating the eye and the object is affected by the luminosity in the eye such that it obtains a similar luminous quality. In this process, the affected cone of air becomes an instrument for the rational soul to perceive the external object through the air's contact with it. ${ }^{79} \mathrm{Al}-M a s$ ùdī addresses the following three defences of intromission, of which I shall briefly discuss the third. The first is that the image of a mountain impressed in the eye is analogous to the image of a mountain impressed in a small mirror; just as, in the latter case, we are able to perceive the large size of the object despite the smallness of the image in the mirror, we can likewise perceive the size of the mountain despite the smallness of the image in our eye and brain. ${ }^{80}$ The second is that double vision is caused by the misalignment of the optical nerves, which results in the brain perceiving the two images impressed in the eyes separately; this indicates that vision consists of the perception of images in the eyes, which are then passed on to the brain. ${ }^{81}$

For the third defence of the theory of intromission, al-Mas'üdi draws on Ishärät II.3.9, where Avicenna argues for the existence of the faculty known as the common sense. We perceive a drop of rain as a line, and this attests that what we perceive is not the drop itself, but rather the image impressed

\footnotetext{
76 Shukūk, 218-227.

77 See p. 4 , n. 14 above.

78 Shukūk, 223-224.

79 Shukūk, 222-223.

8o Shukūk, 218-221.

81 Shukūk, 224-227.
} 
on our faculties, which lingers for a short moment before it fades away. ${ }^{82}$ Al-Mas'ūdì concedes that this observation does indicate the general notion that the process of vision involves the impression of an image, but does not constitute conclusive evidence that the impression occurs in the eye or the brain. His alternative explanation is that since the air separating the eye from the visual object serves as an instrument of vision, the image of the object will become impressed on the surface of the air that touches the object. So it is on that thin film of air that the impression may linger momentarily and be perceived by the soul even after the object has moved to a different location.

Al-Mas' ūdī then refutes Avicenna's theory of the internal senses. He argues, for instance, against the notion of the common sense-a faculty that, according to Avicenna, is located in the anterior ventricle in the brain and receives and integrates the sensory input conveyed to it by the external senses. He submits that this view leads to the clearly absurd implication that the sweetness and heat that one perceives, respectively, in the mouth and on the skin of one's hand should be perceived, as sweetness and heat, once more in the brain. ${ }^{83}$ The upshot of al-Mas'üdì's negation of the internal senses is that the rational soul alone is responsible for all perceptual activity, both external and internal, within the individual, and accordingly that no auxiliary faculties need be postulated to account for any type of perceptual activity. 'All perception belongs to the [rational] soul, and there is no perceiver other than the soul. ${ }^{84}$ The soul, nonetheless, employs the different ventricles of the brain as instruments for different types of internal perception, just as it employs different sense organs (and indeed the air) as instruments for different types of sensory perception. ${ }^{85}$

\section{Section 5. That the Rational Soul is not Imprinted in the Body}

Following on from his treatment of sensory perception in Section 4, al-Mas'ūdī turns to intellection. In Ishārät II.3.16, Avicenna explains that since the intelligibles are indivisible, they cannot become impressed on a divisible thing; so they cannot become impressed within the human body in the same way that sensory images become impressed within the perceiver's sensory organs and brain. The intelligibles, therefore, are perceived by a thing that is neither a body nor imprinted in a body, namely the immaterial rational soul. ${ }^{86}$

\footnotetext{
82 Shukūk, 228-229; Avicenna, Ishārāt, 2, 374-376.

83 Shukūk, 232-233.

84 Shukūk, 236.

85 Shukūk, 236.

86 Avicenna, Ishärät, 2, 404-408. On the soul's intellection of the intelligibles, see, for instance, Gutas, 'Avicenna: The Metaphysics of the Rational Soul'.
} 
Al-Mas'ūdī initiates his criticism by stating that the doctrine that the human soul is an immaterial and indivisible substance is a widely accepted proposition, which is taught unanimously by ancient and later philosophers and prophetic revelations, and that on the basis of prophetic teachings he assents to the doctrine as a religious belief. ${ }^{87}$ There have been attempts, he explains, to support this doctrine with proofs, including Avicenna's proof from the indivisibility of intelligibles, and yet none of the proofs adduced have been apodictic. Al-Mas'ūdī concedes that being indivisible, intelligibles cannot become impressed and represented within bodies, because bodies are divisible. He complains, however, that Avicenna's proof hinges on a false premise, namely that perception is, or at least follows from, the impression of the object of perception within the perceiving faculty, which has already been refuted in Section 4 of the Shukūk. And if perception neither is, nor presupposes, the impression of the perceived within the perceiver, then it will be possible that the soul is a faculty that subsists in the brain, and that it has the capacity for the different types of sensory perception through specific instruments and the capacity for intellection through itself, either independently or with the assistance of the brain which serves as its subject.

Against the notion that perception is, or requires, impression, al-Mas'ūdī reiterates a point he made in Section 4, which is this. I know that the perceiver of all sensibles and intelligibles within me is one. However, if the perception of sensibles requires their presence in the body, and the perception of intelligibles requires their presence in the rational soul, then if I perceive sensibles I will not perceive intelligibles, and if I perceive intelligibles I will not perceive sensibles. ${ }^{88}$

He then considers the argument that knowledge is, without a doubt, an attribute of the knower, and as such must inhere in the knower. If it inheres within the body, the content of the knowledge — that is, the intelligibles-will be divisible. However, since the intelligibles are indivisible, they cannot inhere within the body. Al-Mas'ūdī offers two replies. ${ }^{89}$ The first is that knowledge is an attribute that does not inhere in the knower in the way that colour or temperature inhere in a body. It is rather a 'state that the knower has in relation to the known', and as such indivisible. He analogises it to fatherhood, which is an attribute that a man has in relation to his son, and hence is indivisible despite the divisibility of his body. The second reply is to grant

\footnotetext{
87 Shukük, 239-240. The paragraph is translated on p. 80 below.

88 Shukūk, 241.

89 Shukūk, 242-246.
} 
that knowledge is an attribute that inheres in the knower, without conceding that the divisibility of the substrate of knowledge entails the divisibility of knowledge. For it is arguable that the substrate becomes prepared (musta idd) to receive knowledge only when it is combined of specific parts, such that if it loses its combination by undergoing division it immediately loses the preparedness to receive knowledge and with it any knowledge that inhered therein.

\section{Section 6. That Some Existents are beyond the Grasp of the Senses}

In Ishärāt II.4.1, Avicenna attacks the view that only sensible things exist. ${ }^{90} \mathrm{He}$ argues that universals exist, but are devoid of any accidents concomitant to sensible things, such as having a specific location or quality. Therefore, universals are not sensible things, but purely intelligible existents. In a very brief response, al-Mas'ū ${ }^{\prime}$ complains that universal concepts have no extra-mental existence, but are only intelligible to the mind. To say that they 'exist' in the mind - that they have a 'mental existence'-is misleading, and means nothing other than that the mind knows them. What Avicenna intends to establish is that nonsensible things exist in the extra-mental world, yet he fails to achieve this with his proof.91

\section{Section 7. Establishing the Existence of the Necessary of Existence and the Finitude of Causes}

Discussed in Chapter 5. In Ishārāt II.4.9-15, Avicenna proves the existence of the Necessary of Existence through Itself starting from the existence of possible existents. ${ }^{92}$ An outline of the argument is provided below, and shall not be reproduced here. ${ }^{93}$ Suffice it to say that in the course of the proof, Avicenna opines that if we suppose an infinite series of possible existents, each being an efficient cause that brings the next item in the series into being, the series taken as a whole ( jumla) will be possible of existence, and hence caused by an efficient cause external to the series.

Al-Mas'ūdī attacks the premise that an infinite series constitutes a whole, and hence can be treated as a self-contained set. ${ }^{94}$ Being a 'set', and having a 'totality' or a 'whole', are accidents of finite quantities, for they demand that the

\footnotetext{
9o Avicenna, Ishārāt, 3, 7-9.

91 Shukūk, 246-247. On Avicenna's theory of mental existence, see, for instance, Black, 'Mental Existence in Thomas Aquinas and Avicenna'.

92 Avicenna, Ishārāt, 3, 19-27.

93 See Section 5.1.

94 Shukūk, 248.
} 
quantity be bounded. An infinite series, however, is not bounded; for wherever we postulate a boundary, there will be further items beyond it belonging to the series. Al-Mas'ū $\bar{d}$ goes on to point out that, as it happens, Avicenna treats neither the series of beginningless rotations of the celestial spheres, nor the infinite number of human souls in existence, as having a whole, and hence does not infer that since each item comes to be in time the whole must likewise come to be in time. He argues that Avicenna is right not to do so, considering that both cases involve an infinite quantity of items, and therefore do not constitutes wholes. (Of course, this does not imply that al-Mas'ūdì accepts either of these two doctrines, which are both tied to the theory that the world is pre-eternal.) To be consistent, Avicenna must concede that an infinite series of causes do not make up a whole.

\section{Section 8. Establishing the Oneness of the Necessary of Existence}

In Ishärāt II.4.18, Avicenna establishes the uniqueness of the Necessary of Existence through Itself- that is, the doctrine that only one such being exists. He puts forth a proof that commentators interpret in different ways, mainly because it includes an elimination argument whose disjuncts are not set out and eliminated in full. ${ }^{95} \mathrm{Al}-\mathrm{Mas}$ ūdì begins his commentary with the following tidy interpretation of the argument. ${ }^{96}$ The Necessary of Existence through Itself is individuated as the unique thing it is either $(a)$ because it is necessary of existence, or $(b)$ because of some other factor. If the former $(a)$, then there obviously cannot be another thing necessary of existence through itself. If the latter $(b)$, then either $(b . r)$ the individuation of the Necessary of Existence through Itself is concomitant to Its necessity of existence, or (b.2) Its individuation is accidental to Its necessity of existence, or (b.3) Its necessity of existence is concomitant to Its individuation, or (b.4) Its necessity of existence is accidental to Its individuation. The first (b.r) clearly entails that only one being necessary of existence through itself exists, which is what the argument seeks to establish. If $(b .2)$ necessary existence is accidental to individuation, or (b.4) individuation is accidental to necessary existence, then what is acci-

95 Avicenna, Ishārāt, 3, 36-41; cf. al-Rāzī, Sharh, 2, 263-270; al-Ṭūsī, Hall, 3, 36-40. Avicenna (Ishārāt, 3, 41) concludes the passage by stating, 'And what remains of the disjuncts is impossible', which is vague in the extreme. For an interpretation, which generally agrees with al-Ṭūsī, see Mayer, 'Faḩr ad-Dīn ar-Rāzī's Critique'. I shall not pursue Avicenna's argument here, as it goes beyond the purposes of the present study and has no bearing on al-Mas'ūdì's criticism.

96 Shukūk, 251-252. 
dental to the other must depend on a cause, which entails that the Necessary of Existence through Itself is caused. Finally, if $(b .3)$ necessity of existence is concomitant to individuation, then it must be caused, though this point is left unsubstantiated. (Al-Rāzī explains that this disjunct implies that the existence of the Necessary of Existence through Itself is posterior to Its essence, which entails the absurd conclusion that the essence must exist before it exists.) After eliminating $b .2, b .3$ and $b .4$, disjuncts $a$ and $b .1$ will remain, both of which establish the uniqueness of the Necessary of Existence through Itself. This reading of Avicenna's argument was later developed by both al-Rāzī and al-Ṭūsī, each in his own way.

Having set out the argument, al-Mas'ūdī turns to the offensive, his central complaint turning on the terms 'necessary existence' and 'individuation'. Avicenna considers necessary existence to have a distinct and irreducible reality (amr wujūdī) over and above existence (haqīqa muhașșala thābita wară alwujūd). For al-Mas'ūdī, however, all that 'necessary existence' means is that an existent does not depend on a cause that produces its existence- that is, an efficient cause. ${ }^{97}$ As such, it is nothing but a sheer negation (salb mahd wa'adam șirf), and has no reality over and above existence. Al-Mas'üdī argues that the same goes for 'individuation', which, quite simply, means that an entity is differentiated from other things, and this does not necessarily require a feature that exists over and above the thing's essence. With these two clarifications, he proposes to leave aside (for the moment) the ambiguous term 'necessary existent', and to reformulate Avicenna's question thus: Why is it impossible that there be two uncaused existents? From this, al-Mas'ūdì goes on to argue that if necessary existence is defined negatively, Avicenna's proof will collapse. ${ }^{98}$

In the course of the ensuing discussion, al-Mas'ūdì considers the following reductio argument. ${ }^{99}$ If we postulate two uncaused existents, they must be differentiated from each other. So each is differentiated from the other either by its essence, or by some existent thing that it has over and above its essence. If the former, the existence of each would be accidental to its essence and hence caused. And since an essence cannot cause its own existence, the cause of each of the two existents must be external to it. However, if the latter, then either one or both of the entities would possess something that is superadded to its

\footnotetext{
97 Shukūk, 252-253. Al-Mas'ūdī is clearly influenced by al-Ghazālī here (cf. Tahāfut, 138-139; 144-145).

98 Shukūk, 254.

99 Shukūk, 258.
} 
essence; so one or both would be composite, and composite things are caused. Either way, the postulate that the two existents are uncaused does not hold. This argument invokes Avicenna's doctrine of the simplicity of the Necessary of Existence through Itself, according to which It has neither an essence nor other positive attributes over and above its necessary existence. Al-Mas'ū ūi refers to Ishārāt II.4.21-22, where this doctrine is asserted. ${ }^{100}$

At this point, our commentator turns his attention to the Avicennan doctrine of divine simplicity. He refers to, and draws upon, the thorough rebuttal that al-Ghazālī deploys in the Tahäfut. ${ }^{101}$ Al-Mas'ūdì complains that if 'necessary existent' is defined as 'not caused by an efficient cause', the contention, 'If existence is concomitant to an essence it cannot be a necessary existent, i.e. it must be caused', will be a baseless assertion, as it is not substantiated with any proof. All that the proof discussed in Section 7 establishes, assuming it is sound, is the existence of an uncaused existent; but it sheds no light on whether or not this existent has an essence. Along the same lines, he avers that there is no proof that an entity whose existence is uncaused cannot possess an attribute over and above its essence. To describe such an entity as 'composite' will amount to nothing, unless it is shown that either the attribute or the entity's existence is caused. Al-Mas'ūdī concludes that there is, in fact, no impossibility that the First Cause (God) has an essence and pre-eternal positive attributes that subsist in His essence, a position that clearly accords with Ash'arī theology.

\section{Section 9. That the Continued Existence of the Effect Depends on the Continued Existence of Its Cause}

Discussed in Chapter 3. In Ishārät II.5.1-3, Avicenna argues that a possible thing depends on its (metaphysical) efficient cause (that is, the cause of its existence), not only for its coming-to-be, but also for its continued existence. ${ }^{102}$ In other words, possible existents have no inherent persistence that sustains them in existence after they have come to pass, but must be sustained constantly in existence by an efficient cause. The same view is implied in Ishärāt II.4.10.103 To substantiate his point, Avicenna sets up an elimination argument: a thing that comes to be depends on its cause either $(a)$ for its existence, or $(b)$ for its

\footnotetext{
100 Avicenna, Ishārāt, 3, 44-46.

101 Shukūk, 259-261; al-Ghazālī, Tahāfut, Discussions 5-8, where Avicenna's doctrine of divine uniqueness and simplicity are attacked.

102 Avicenna, Ishārāt, 3, 57-70.

103 Avicenna, Ishārāt, 3, 20.
} 
prior non-existence, or $(c)$ for the temporal posteriority of its existence to its nonexistence. He eliminates ' $b$ ' and ' $c$ ', and by doing so establishes ' $a$ '. ${ }^{104}$

Al-Mas'ū dī rejoins that most possible existents do enjoy inherent continued existence, and hence do not need to be sustained in existence by an agent. He makes only two exceptions. ${ }^{105}$ Some accidents need to be renewed constantly by a cause, such as motion in space, which needs to be renewed constantly by an inclination (mayl) that supervenes on the object. Other accidents are contrary to the nature of the subject in which they inhere, and are sustained by a constant force (qasr) applied by an external agent, an example being heat that is forced on water by fire. Yet observation of forced accidents, al-Mas'ùdì goes on to argue, will provide confirmation of the central principle, that possible existents continue to exist of themselves, independently of a cause. For instance, when water is removed from the fire, the heat forced upon it will continue to exist for a while, even though its agent has become absent. Al-Mas'ū $\overline{\text { di }}$ then dismisses a possible counter-explanation, namely that even though a form is produced by an agent, it will be preserved in existence by the matter in which it subsists, since matter must always have some form or other. This notion that matter is a preserving cause ('illa mubqiya) for form is not one that Avicenna holds. ${ }^{106}$

At the end of the section, al-Mas'ūdī refutes Avicenna's elimination argument. He has no quarrel with the elimination of disjuncts ' $b$ ' and ' $c$ ', yet he does not concede ' $a$ ', on the grounds that Avicenna omits to consider a fourth disjunct, namely $(d)$ that a thing that comes to be depends on an agent on account of the effect's 'coming from nonexistence into existence'. This occurrence, an affection, is what the expression 'coming-to-be' (ḥudūth, ḥuṣūl) denotes, and it is strictly speaking the effect produced by the agent. As to the realised outcome (hâsạil) of the affection, it is not dependent on an agent. ${ }^{107} \mathrm{Al}-\mathrm{Mas}$ ' $\mathrm{u} d \overline{\mathrm{l}}$ concludes that a thing that comes to be depends on its agent only for its coming-tobe, but not for its continued existence, and that coming-to-be cannot endure constantly, as it must be preceded by non-existence. This suggests that the discussion serves as an attack on a cornerstone of the doctrine of the pre-eternity of the world, and a defence of creation ex nihilo.

104 For the detailed argument, as well as a discussion of Avicenna's doctrine, its background and its criticism by al-Ghazālī, see Sections 3.1-4 below.

105 Shukūk, 262-263.

106 See the discussion on pp. 102-103 below.

107 For more detail on this view and on its possible Māturīdī inspiration, see pp. 104-107 below. 


\section{Section 10. That the Possibility of Coming-to-be is an Attribute That Exists prior to Coming-to-be}

Discussed in Chapter 4. Ishärāt II.5.6 argues that a thing that comes to be (hâadith) must be possible of existence in itself before its coming-to-be; for otherwise it would be impossible of existence. Therefore, this possibility must obtain (hâșil), and it can only obtain in a subject. ${ }^{108}$ In this way, Avicenna conflates the notion of possibility with the Aristotelian theory of potentiality. ${ }^{109}$ As al-Mas'üdì points out at the start of his commentary, by establishing that all that comes to be must be preceded by a substrate and potentiality, Avicenna infers that matter is pre-eternal and consequently that the world is beginningless.

Our commentator queries the contention that a thing that comes to be must be possible of existence before it comes to be. ${ }^{110}$ 'Possibility', he argues, is an expression 'common (mushtarak) to two meanings'. The first is the metaphysical, per se possibility connected to essence; and this possibility is immutable and not dependent on the conditions of any substrates and their receptivity to the possible form. The second is the natural, dispositional preparedness (istic $\bar{a} \bar{d}$ ) that a particular substrate possesses to receive a form. Prior to their coming-to-be, things that come to be must be possible in the former sense, but they need not necessarily be possible in the latter sense. Things that come to be in a substrate must indeed be preceded by their preparedness in that substrate. However, things that do not exist in a substrate need not be preceded by preparedness. The obvious implication is that matter can come to be ex nihilo (though this raises the problem that the first form to subsist in matter must too come to be ex nihilo without being preceded by preparedness, considering that matter cannot exist without form, and that the two must therefore come to be simultaneously).

Concluding the section, al-Mas'ūdī praises the 'powerful objections' that al-Ghazāli puts forth in the Tahäfut against this Avicennan argument for the pre-eternity of matter. He summarises al-Ghazâli's argument that Avicenna contradicts himself by maintaining that things can only come to be if they are preceded by their possibility-in-matter, and that the human soul comes to be not in a substrate. ${ }^{111}$

\footnotetext{
108 Avicenna, Ishārāt, 3, 78-84.

109 For more details on Avicenna's argument and notion of possibility-in-matter, and on al-Ghazāli’'s criticism, see Sections 4.1-2 below.

110 Shukūk, 271-273.

111 Shukūk, 273-274. For details, see Section 4.2 below.
} 


\section{Section 11. That from One Only One Effect Can Proceed}

In Ishārāt II.5.11, Avicenna defends his well-known principle that from a cause that is absolutely one, only one effect can derive. ${ }^{112}$ As already mentioned, he appeals to this principle in various contexts in his philosophy, most importantly his Neoplatonic account of the procession of multiple existents from the Necessary of Existence through Itself, which is absolutely simple. Avicenna maintains that being truly one and simple, the First Cause produces only one simple effect, namely the First Intellect. Al-Mas'ūdi notes in the conclusion of the Shukük the connection between this doctrine and the theory of the heavenly intellects, which function as mediating causes through the agency of which the sub-lunar world ultimately comes to be. ${ }^{113}$

Avicenna substantiates the principle in question using the following reductio. The conception (mafhüm) that a thing causes effect $\mathrm{A}$ is different from the conception that it causes effect $B$. If we suppose that a thing $C$ is absolutely one, and yet causes each of $A$ and $B$, it will have the conception of being the cause of $\mathrm{A}$ and the conception of being the cause of $\mathrm{B}$. These two conceptions must be due to $\mathrm{C}$ having two distinct aspects (haythiyya), each with its own distinct reality, and these two aspects will either be constituents (muqawwim) of the essence of $\mathrm{C}$, or concomitants (läzim) to it. If the former, $\mathrm{C}$ will be composite, which contradicts the supposition that it is simple. If the latter, the two concomitants will themselves be engendered by two aspects of $\mathrm{C}$, leading to the same contradiction. Therefore, an absolutely simple cause cannot produce more than one simple effect.

Al-Mas' 'ùdī begins by reiterating his criticism of Avicenna's contention that the Necessary of Existence through Itself is absolutely simple. In a passage that strongly echoes the Ash'ari theory of attributes, he contends that it is not impossible that the Necessary of Existence through Itself has an essence, or that certain attributes subsist in Him. ${ }^{114}$

Al-Mas' $\bar{u}$ dì then attends to the principle that from one only one derives, and proceeds with a question: Must the effect be one in quantity, or one in kind? If Avicenna intends the former, then his argument fails to exclude the latter. Al-Mas'ùdì argues that it is indeed possible, if A and B belong to the same

112 Avicenna, Ishārāat, 3, 97-102; cf. Ilāhiyyāt, IX.4, 403-405. On this principle, see, for instance, D'Ancona, 'Ex Uno non fit nisi Unum'. The principle is refuted in Discussion 3 of al-Ghazālī's Tahäfut (110 ff.) to make way for the theological doctrine that God creates everything directly.

113 Shukūk, 288; p. 50 above.

$114 S h u k u \bar{k}, 275^{-276}$. The passage is translated on p. 36 above. 
kind, for $\mathrm{C}$ to produce them both by virtue of having only one causative aspect. However, if Avicenna intends the latter, then it will be argued that existence insofar as it is existence is one in kind, though it is numerically multiple purely on account of the multiplicity of individual existents. So it is possible, al-Mas'üdī reasons, for existence to issue from the First and to overflow ( $f a \bar{d} d a)$ onto all simple essences, be they intellects or elements, given that all caused things are caused with respect to their existence, but not with respect to their essence. He analogises the process to the light that flows from the sun by the effect of only one aspect thereof-namely, its luminous nature-but is nonetheless received by multiple bodies.

Al-Mas'ūdī concludes by advancing an ad hominem (ex concessis) argument starting from the doctrine of the Active Intellect, to which Avicenna ascribes the provision of substantial and accidental forms to matter. These forms, he opines, are endless in quantity, yet Avicenna would not concede that the Active Intellect possesses an endless number of corresponding aspects. So if Avicenna maintains that the Active Intellect produces multifarious forms without having multiple aspects, then he should concede the possibility that the First Principle overflows existence directly onto all simple essences.

\section{Section 12. That the Activities of Corporeal Powers are Finite}

In the course of setting out his emanationist cosmology in Ishārät II.6, Avicenna defends the Aristotelian doctrine that a finite body cannot produce infinite motion, and that since the motion of the heavens is infinite it must have an immaterial mover. ${ }^{115} \mathrm{Al}-M a s^{\prime} \mathrm{u} d \overline{1}$ targets the following reductio ad absurdum adduced by Avicenna in support of this theory. ${ }^{116}$ The motion produced in a body can either be forced upon it by a power external to it, or produced by a power natural and internal to it. Let us suppose that an external power inheres in a given body, and hypothesise that it moves another body $B_{1}$ from a certain starting point for an infinite duration of time. $B_{1}$ will traverse an infinite distance. Now suppose that the same power moves a smaller body $B_{2}$, which is identical in nature to $B_{1}$, from the same starting point. Being smaller, $B_{2}$ will move faster than $B_{1}$, and hence will traverse a longer distance in any given duration. This means that the distance traversed by $B_{2}$ must be longer than an infinite distance, which is a contradiction. Therefore, the initial assumption that a body can produce infinite forced motion in another body must be false.

\footnotetext{
115 Aristotle, Physics, VIII.1o. On this doctrine and its reception in late antiquity, see Sorabji, Matter, Space and Motion, $249 \mathrm{ff}$.

116 Avicenna, Ishārāt, 3, 165-169.
} 
That a body could be moved infinitely by its own natural power is then excluded along similar lines. ${ }^{117}$

The core of al-Mas'ūdī's objection is that being equal to another, or being greater or smaller than another, are accidents of finite quantities. ${ }^{118}$ So if two infinite quantities are postulated, they cannot be equal to each other, nor can either of them be smaller or greater than the other. If we juxtapose in the mind two infinite series, neither can be longer than the other, since neither can possibly have an additional quantity over and above the point at which the other terminates.

He then advances an ad hominem (ex concessis) argument starting from the philosophers' theory that the motions of the celestial spheres are beginningless - a case in which the series is infinite a parte ante and finite in the present, rather than finite in the present or at some point in the past and infinite a parte post as postulated in the problem at hand. ${ }^{119}$ Take, for instance, the motion of the spheres of the moon and Saturn. The former sphere rotates faster than the latter. Avicenna must concede either that the sphere of the moon has rotated more times than the sphere of Saturn, or that it has not rotated more times. If the former, one infinite quantity would be greater than another infinite quantity. If the latter, the difference in the speed of motion between the two spheres will not entail a difference in the quantity of rotations completed during an infinite period of time. Either concession will contradict Avicenna's assertions in the proof under discussion.

\section{Section 13. That the Human Soul is not Affected by the Loss of the Body through Death}

At the start of Ishārāt II.7, Avicenna advances one of his two arguments for the immortality of the rational soul. ${ }^{120} \mathrm{He}$ had already established that the soul is not imprinted in the human body, but exists separately from the body and uses it as an instrument, and that the soul has a celestial cause. It follows that the soul survives the corruption of the body. In the following passages (Ishārāt II.7.2-4), which al-Mas'ūdī targets, Avicenna goes on to argue that the soul's intellectual activity too is not affected by the death of the body. ${ }^{121}$ Since intellection is essential to the soul, and since the soul obtains the intelligibles from the

\footnotetext{
117 Avicenna, Ishārāt, 3, 170-174.

118 Shukūk, 280.

119 Shukūk, 281.

120 Avicenna, Ishārāt, 3, 241-243.

121 Avicenna, Ishārāt, 3, 244-252.
} 
Active Intellect and not from the body, the death of the body will not adversely affect the soul's intellection. Were intellection dependent on the body, it would deteriorate with the deterioration of the body's health. Avicenna adduces further arguments confirming that though the body is an instrument of the soul, it does not serve as an instrument for the soul's intellection. For instance, as the body ages, its motive and sensory faculties deteriorate, while the intellectual faculty either remains constant or continues to develop. Moreover, intense and persistent activity causes exhaustion to bodily faculties; however, the intellective faculty is not affected in the same way, but often grows stronger with intense and persistent exercise.

In Section 5 of the Shukūk, al-Mas'ūdī briefly describes these arguments as non-apodictic and merely persuasive. ${ }^{122}$ Here, in Section ${ }^{13}$, he dismisses as unsubstantiated Avicenna's premise that the deterioration of bodily organs does not bring on intellectual degeneration, and counters that in fact whenever the brain is damaged, the individual's sensory and intellectual perception degenerates, which suggests that the brain is the soul's instrument for intellection. ${ }^{123}$ However, even if it is granted that intellection, as Avicenna asserts, is essential to the soul and not a function of the body, it can still be claimed that the brain serves as a subject in which the soul inheres. The soul, accordingly, would be corrupted with the corruption of the body.

\section{Section 14. That the Human Soul Cannot Possibly Pass Away}

Discussed in Chapter 4. In Ishärāt II.7.6, Avicenna argues that the human soul is incorruptible in itself. The argument is basically this. A corruptible thing must consist of two principles, one that provides it with actuality as the thing it is, and another that provides it with the potentiality to pass away, i.e. to be replaced with something else. Therefore, since the human soul is self-subsistent and not a compound of two principles, it is incorruptible. ${ }^{124}$

Al-Mas'ūdī raises two complaints. The first is that Avicenna's argument is premised on the principle that occurrences must be preceded by possibilityin-matter, which was already refuted in Section 10. The second is the following ad hominem argument. The possibility of the coming-to-be of the human soul either inheres in a substrate (in which case, the substrate must be the body), or does not inhere in a substrate. If the former, then the possibility of the passingaway of the human soul too may inhere in the human body. If the latter, then

\footnotetext{
122 Shukūk, 239-240.

123 Shukūk, 282-283.

124 Avicenna, Ishārāt, 3, 261-264. For details, see Section 4.4 below.
} 
it will be possible for the soul to pass away, without this possibility having to inhere in a body. Either way, the human soul is corruptible.

\section{Section 15. [The Knowledge that the Necessary of Existence Has of Itselfand of Things Other than Itself ]}

The concluding section is only given a number, but not a substantive title. It begins by citing Ishārāt II.7.15 and II.7.21, and then highlights three Avicennan views concerning the knowledge of the Necessary of Existence through Itself. ${ }^{125}$ Al-Mas 'ùdī does not discuss any, but only refers to al-Ghazālì's refutations in the Tahäfut. ${ }^{126}$ Here is a full translation of his commentary:

These [two passages submit] three claims. The first is that [the Necessary of Existence] knows Itself. The second is that It knows [things] other than Itself. The third is that It does not know particular things, except in a universal way. Concerning each of these [claims], there are powerful objections $(s h u k u \bar{k} k)$ and serious problems (ishkālāt). The Imām al-Ghazālīmay he be blissful, and may God sanctify his noble soul_-provided these in the Tahäfut in a way that cannot be matched, and there is hence no point in reproducing them here. Whoever wishes to acquaint himself with them must read that book; for all that is found in that source is precious. $^{127}$

\subsection{Interpretation: Al-Mas' 'ū dī's Philosophical Theology}

The preface and conclusion of the Shukūk quoted and discussed in Section 2.2 above leave unanswered a few questions concerning what the author endeavours to achieve in his book, especially as they should not readily be taken at face value, as noted. So we should hone in on our text, and try to assess the overall thrust and objectives of the criticisms it deploys against the Ishärāt. What is al-Mas'ūdī's 'agenda', so to speak? And does this agenda have more in common with al-Ghazālī's critical theology, or with Abū l-Barakāt's critical philosophy? ${ }^{128}$

\footnotetext{
125 Avicenna, Ishārāt, 3, 278; 3, 295-296.

126 Al-Ghazālī, Tahäfut, 210-238.

127 Shukük, 287. The concluding statement is an Arabic proverb that cannot be rendered literally.

128 It is worth pointing out here that al-Mas'ū ūi composed the Shukūk before meeting al-Rāzī and most probably before reading any of his works. So we can immediately discount the
} 
To begin with, al-Mas'üdì's conceptual toolkit is thoroughly philosophical, including where his own views are expressed. From the preceding synopsis, it is obvious that he subscribes, for example, to the theories of hylomorphism, universal essences, natural causality and the rational soul, theories which are almost never tolerated in classical kaläm sources on account of their direct conflict with the theologians' atomism and occasionalism. What is more, there is a conspicuous absence in the Shukük of any of the conceptual vocabulary of kalām. For example, al-Mas'ūdī uses the terms 'First Principle' and 'Necessary of Existence through Itself' repeatedly, but nowhere any of the more religious appellations of the deity such as 'God' (Allāh) or 'Creator' (khāliq, bāri'), except in formulae. Likewise, instead of 'creation' (khalq), he uses 'procession' (șudür) and 'overflowing' ( fayd), though whether the commentator is genuinely committed to these notions or only employs them for dialectical expediency is far from certain. ${ }^{129}$ Despite its thoroughly philosophical conceptual vocabulary, the book exhibits much of the non-conceptual, dialectical vocabulary and argumentative structure and tactics characteristic of earlier kalām, most obviously the question-and-answer format ('If they say ..., we say ...' in qā lū ... qulna ...).

Yet al-Mas'ūdì's conceptual vocabulary is only one part of the story. What he does with it is another matter. And it seems to me that the problems treated in the Shukūk fall into three classes-natural philosophy and mathematics, the ontology of the human soul, and metaphysics - and that each of these classes exhibits its own distinct motivating objectives.

1. Natural philosophy and mathematics. The first class includes discussions that fall under, or are closely linked to, physics and mathematics, specifically Sections $1-4 .{ }^{130}$ These discussions have a twofold background. First, they tie in with al-Mas'ūdi's career in the sciences, particularly the mathematical sciences, which has already been highlighted in Chapter $1 .{ }^{131}$ Most notably, his expertise in geometry and geometrical optics comes to the fore in Section 2 of the Shukük and in the discussion of vision in Section 4. Second, discussions of natural philosophy in the book bespeak the influence of Abū l-Barakāt's Mu'tabar,

possibility that he was in any way either influenced by his younger contemporary, or responding to him.

129 With one exception: life is 'created' in a foetus (Shukūk, 208).

130 Although Avicenna considers Problems 1 and 2 to belong properly to metaphysics, they concern principles of natural philosophy, which is why he covers these problems alongside other physical topics, at the beginning of the second part of the Ishärāt (cf. Avicenna, Tabīìyyāt, I.I.2, 13-26).

131 See Sections 1.2-3. 
which is cited explicitly no less than three times in Section 4. The first citation highlights his opposition to a widely accepted Avicennan position, and runs as follows:

The view that perceivers divide into bodily ones, which only perceive sensible objects, and non-bodily ones, which only perceive intelligibles, is a widely accepted view received on authority (mashhür maqbül) and agreed upon by the majority. The only one to go against this is the most excellent person of our time, whom God favoured with a superior [skill for] research and inquiry, the author of the Mutabar, may God reward his deeds and recompense him well. If you apply an impartial method, abandon prejudice and partisanship, and give reasoned consideration to the different doctrines, you will know that his is the correct position. ${ }^{132}$

Abū l-Barakāt's influence is also palpable in Section 1 of the $S h u k u \bar{k}$, as we shall see in Chapter 6 below. Going further, al-Rāzī remarks in the preface to his Jawābāt that most of al-Mas'ūdì's criticisms are borrowed from Abū l-Barakāt, but this seems an exaggeration. ${ }^{133}$

None of the discussions of natural philosophy in the Shukük are motivated by direct or explicit theological concerns, and only one, to my mind, may have an indirect and unstated theological objective. In Section 4, which focuses on human perception, al-Mas'ū $\bar{d}$ ì assigns all types of perception to the rational soul and externalises the process of sensory perception such that objects are perceived in the external world and not within the perceiver. ${ }^{134}$ Perception, accordingly, consists not of the representation of the object perceived within the perceiver, but instead of a relation that the perceiver has to the external object. Abū l-Barakāt appeals to this theory of perception to establish, in opposition to Avicenna, that God knows particular things without undergoing change or requiring bodily organs, a position that Ibn Sahlān al-Sāwī responds to in defence of the Avicennan thesis together with its underpinning theory of perception. ${ }^{135}$ Though he does not indicate the theological relevance of his

\footnotetext{
132 Shukük, 215.

133 Al-Rāzì, Jawābāt, 11; cf. 19; 29; 39; 49. On al-Rāzī's remarks on the sources of the Shukūk, see Shihadeh, 'Al-Rāzì's Response', 4.

134 See pp. 64-65 above.

135 Abū l-Barakāt, Mu'tabar, 3, 69ff. Al-Sāwī (Nahj al-taqdīs, 31) responds to Abū l-Barakāt's views as reported in an unidentified epistle penned by a contemporary, which suggests that he did not have access to the Mutabar.
} 
own discussion of perception, al-Mas'ūdī is likely to have intended it ultimately as a response to such defences of the Avicennan position, probably even to al-Sāwì's Nahj al-taqdīs specifically, to lend support to the doctrine that God knows particulars. His espousal of this doctrine is declared in Section 15 of the Shukūk.

2. The ontology of the soul. The second class includes discussions of the ontology of the human soul, more specifically its immateriality and immortality. These are Sections 5, 13 and 14, though Section 3 may also be included. In my view, these discussions are motivated in the first place by considerations of theological epistemology, which al-Mas'ū ū declares in Section 5 where he remarks on the doctrine of the immateriality of the human soul as follows:

This is a widely accepted proposition, which is agreed upon by both ancient and later [philosophers], taught in all true religions, and made known through revelation and the light of prophecy to prophets and messengers, the blessings of God be upon them all, who informed us of the survival of [the soul] after death. An accident does not continue to exist after the passing away of the substrate; [therefore, the soul is not an accident, but a substance]. So we have accepted this from them by way of faith in the Unseen, assent and belief (ìmānan bi-l-ghayb wa-tașdīqan wa-itiqādan), having devotionally subscribed to their teachings, peace be upon them. ${ }^{136}$

He avers that the proofs adduced for this doctrine by those who search out the realities of things and strive to rise above traditional belief (taqlid) are all non-apodictic, and he goes on to argue that this is true of the Avicennan proof under discussion. What this reveals is that al-Mas'ūdī follows earlier theologians, including al-Ghazâlī, in maintaining (1) that the nature of the human soul is unknowable to the mind and can only be established through prophetic revelation, which presupposes that revelation provides knowledge of certain 'unseen' things that are otherwise unknowable, and (2) that since the soul, as revelation teaches, survives the death of the body and continues to exist separately from it, it must be a substance rather than an accident. ${ }^{137}$ Follow-

136 Shukūk, 239-240.

137 On both points, see Shihadeh, 'Classical Ash`arī Anthropology', 465 ff. So al-Mas'ūdī's epistemological stance goes back ultimately to classical kalām, and pertains primarily (or, as far as the problems treated in the Shukūk are concerned, exclusively) to the ontological 
ing al-Ghazâli's model, however, he maintains that the soul is an immaterial substance, rather than a 'subtle body' embedded in the human body, as some earlier Ash'aris opined. ${ }^{138}$ It is safe to assume that the same epistemological stance elicits al-Mas'üdì's confutation of Avicenna's arguments for the immortality of the soul in Sections 13 and 14, and is possibly at play in Section 3, which targets Avicenna's argument that the soul is different from the temperament.

3. Metaphysics. The third class of discussions includes Sections 6-12 and 15, which concern metaphysical problems, especially problems concerning the nature of the First Cause, cosmogony and cosmology. Although at first glance these appear to reflect the same overall critical outlook that motivates sections on physics and mathematics, on closer inspection a different underlying narrative emerges, which resonates with the theological perspective already encountered at the beginning of Section 5 . The most conspicuous clue lies in the following references made to al-Ghazāli's Tahäfut, the only source other than Abū l-Barakāt cited in the Shukūk. In the first, al-Mas'ūdī introduces as follows a response evoked by an Avicennan argument: 'The response (jawāb) to this is what the Imām al-Ghazālī — may he be blissful and may his soul be sanctified-provided in the Tahäfut and set out in a most superlative manner. ${ }^{139}$ In the second, he references the same source, this time to support his own line of criticism:

All of this [i.e. al-Mas'ūdī's own criticisms of Avicenna] finds support in what the Imām al-Ghazālī_may he be blissful—provided in the Tahäfut in response ( $\mathrm{radd}$ ) to their [i.e. the philosophers'] views on this question. They are all potent objections (ishkālāt), and very much on target. ${ }^{140}$

The final reference occurs in Section 15, a very short section which I have already cited in full. ${ }^{141}$ Obviously, therefore, the Tahäfut had a decisive effect on the metaphysical discussions in the Shukūk. A direct Ghazālian influence

status of the soul. I should add that I do not subscribe to the view that al-Ghazālìs Tahāfut is largely motivated by the conviction that reason cannot arrive at truth without the aid of revelation. This question, however, goes beyond the purview of the present study and demands a separate treatment.

138 Some earlier Ash'arīs believed the soul to be an accident. See Shihadeh, 'Classical Ash'arī Anthropology', 465ff. On al-Ghazālī's views, see Shihadeh, 'Al-Ghazālī and Kalām'.

139 Shukūk, 259.

140 Shukūk, 273.

141 See p. 78 above. 
is detectable even in metaphysical discussions in which the Tahäfut is not cited-for instance, in Sections 7, 9 and 14, as the case studies conducted in the following chapters will illustrate. This is hardly surprising, as we have already established al-Mas'ūdì's broader intellectual debt to al-Ghazālī on the basis of sources other than the Shukūk, most notably al-Rāzī, Ibn Ghaylān and al-Mas'ūdī's own Sharh al-Khuța. ${ }^{142}$

Yet the Ghazālian impact on the Shukūk is not confined to the specific arguments reproduced or developed by al-Mas'ūdī, but informs the very 'agenda' of the book. We have already seen that in Sharh al-Khuța he exhibits a keen interest in theological themes, although there he commits himself to a neutral and expository reading of the main text. A similar focus on theological questions is attested in the choice of metaphysical problems attended to in the Shukūk, though now Avicenna's doctrines are treated critically, the overall thrust of the criticisms being to sustain competing theological positions. Although the underlying theological commitments and motives are not declared openly in any metaphysical discussions, they are unmistakable. In Sections 8 and 11, al-Mas'ū '̄ì attacks Avicenna's doctrine of God's absolute simplicity, and argues instead that it is possible that He has an essence and (as Ash'arīs hold) attributes over and above His essence. ${ }^{143}$ In Sections 9 and 10, he criticises two prime underpinnings of the theory of the pre-eternity of the world, and champions antitheses each of which entails that the world is created in time, ex nihilo. In Section 11, al-Mas'ūdì complains against the principle that the First Cause produces only one effect, on which Avicenna's account of the Neoplatonic theory of emanation is premised, and he submits the alternative thesis that the First Principle could confer existence on all possible things directly. His disapproval of Avicenna's cosmogony finds expression also in the conclusion of the Shukūk, cited previously. Yet perhaps the most telling indication of the commentator's theological motives lies in Section 15, quoted above, where he simply refers us to al-Ghazâlī's refutations of Avicenna's views on God's knowledge in Discussions 11-13 of the Tahäfut. ${ }^{144}$ This reference evinces an acceptance of the upshots of al-Ghazāil's refutations, most notably the theological tenet that God knows particulars. With its criticisms of metaphysical doctrines evidently intended to lend credence to certain widely held theological views, the Shukūk displays some of the hallmarks of al-Ghazālī's critical and dialectical style of theology, which underlies the latter's criticism of Avicennan

\footnotetext{
142 See Section 1.4 above.

143 See pp. 69-70 and 74 above.

144 See p. 78 above.
} 
philosophy in defence of the orthodox creed. Yet, in sharp contrast to al-Ghazālī and Ibn Ghaylān, al-Mas ū $\overline{d i ̄ ~ u n d e r t a k e s ~ h i s ~ c r i t i c i s m ~ o f ~ A v i c e n n a n ~ d o c t r i n e s ~ i n ~}$ a much more restrained manner, nowhere declaring any religious motives nor partaking in anti-Avicennan polemic.

The fact that a theological undercurrent is detectable in the Shukük mainly in discussions of metaphysics and the ontology of the soul, more so than in discussions of other branches of natural philosophy and mathematics, also corresponds, to a degree, to the Ghazālian kalām project epitomised in the Tahāfut. Al-Ghazālī directs his attention primarily to critiquing doctrines of metaphysics and human ontology (to which he dedicates, respectively, sixteen discussions and three discussions), and much less so to other areas of natural philosophy (which receive only one discussion, namely Discussion 17, on causation, which in fact is highly pertinent to theology), because, as he writes, the bulk of the philosophers' metaphysical doctrines are false, whereas the bulk of their natural philosophy is acceptable. In his view, the majority of the philosophers' physical theories and almost the entirety of their mathematical theories, just like medicine, are sound and do not clash with the teachings of revelation. ${ }^{145}$ This broad assessment in effect gives a green light to a more positive partaking in philosophical physics and mathematics; and, to my mind, it is this outlook that explains the absence of theological motives, direct or indirect, in some sections on physics and mathematics in the Shukük.

In view of this Ghazālian influence, should we class the Shukūk as a Tahäfutstyle work, without the rough edges? I am inclined to think not, as fundamental differences exist between al-Mas'ū $\mathbf{d}$ and his predecessor. The Tahäfut is a largescale refutation executed very much from the perspective of an 'outsider', albeit one who avowedly is willing to take onboard whatever philosophical views prove sound and worthy. It is fixed exclusively on refutation, as al-Ghazālī generally abstains in this book from the more constructive business of establishing the Sunni creed ('aqidat ahl al-sunna, as he calls it) or any other positive doctrines. The latter task is assigned to other works, such as the Iqtișād, a kalām manual. ${ }^{146}$ In contrast, the Shukūk offers an 'insider', philosophical critique of a philosophical system. As an aporetic text, al-Mas'ūdì's work displays greater precision and selectiveness in the Avicennan views it targets, and the criti-

145 Al-Ghazālī, Maqāṣid, 3; Munqidh, 79-85. Al-Ghazālī also explains that the philosophers' logic is mostly correct.

146 On al-Ghazālì's view that the principal objective of kalām is to defend the Sunni creed, see his Munqidh, 71-72. For earlier Ash'arīs, by contrast, the objective of kalām is both to establish and to defend the creed. 
cisms it deploys are much more pinpoint in scope and implications. What is more, al-Mas'ū $\mathbf{u}$ ì counters many Avicennan doctrines by submitting and sometimes defending views of his own. These, for the most part, concur with widely held religious doctrines, but are nonetheless formulated and justified in wholly philosophical terms. (By 'religious doctrine' here, I mean the skeletal Sunni creed, as understood by al-Ghazālī, abstracted from the theoretical exposition and defence that surrounds it in kalām. ${ }^{147}$ ) Therefore, the metaphysical discussions of the $S h u k \bar{u} k$ can be read as being attempts to develop philosophical formulations of certain central creeds that were previously couched in the framework of kalām. They are evidence of a nascent philosophical theology, which, to an extent, was still inchoate and unsystematic. That the big question of whether philosophy and revelation are, or can be, in agreement (muwäfaqa) is likely to have been at the back of al-Mas'ūdì's mind when he wrote the Shukük is already suggested by the fact that this question motivates his commentary on Avicenna's Khuṭba, as we have seen. The latter text tries to show, through exegesis, how Avicennan philosophy is in harmony with the teachings of revelation, though the commentator, of course, is noncommittal about the contents of his book. The Shukük seems motivated, in part, by the same basic conviction that philosophy need not clash with the teachings of revelation, but it pursues this objective by critiquing aspects of Avicennan philosophy and proposing alternative philosophical theories and arguments.

147 Cf. Ibn Khaldūn's distinction between religious doctrines (al-'aqā’id al-imañniyya) and the rational proofs (dalīl 'aqlī, hujja 'aqliyya) adduced by theologians (Shihadeh, 'Argument from Ignorance', 218). 